\title{
Biochemical properties of thiaminase, a toxic enzyme in the gut of grasshoppers (Zonocerus variegatus Linn)
}

\author{
Leonard O. Ehigie ${ }^{1}$, Raphael E. Okonji2+, Folashade A. Ehigie ${ }^{1}$ \\ 1Department of Biochemistry, Ladoke Akintola University of Technology, Ogbomoso, Nigeria. \\ 2Department of Biochemistry, Obafemi Awolowo University, lle-Ife, Nigeria. \\ + Corresponding Author: okonjire@yahoo.co.uk ; reokonji@oauife.edu.ng
}

\begin{abstract}
The variegated grasshopper, Zonocerus variegatus (Linn) (Orthoptera: Pyrgomorphidae) is eaten mostly in the South western region of Nigeria. Thiaminase is a toxic enzyme present in some foods. The activity of thiaminase in the gut of Zonocerus variegatus is described. The enzyme was isolated using DEAE- Cellulose ion exchange chromatography and gel filtration on Biogel P-100. The enzyme had a specific activity of 7.9 unit per milligram of protein. The enzyme exhibited a maximal activity at $\mathrm{pH} 8.0$ and $\mathrm{K}_{\mathrm{m}}$ of 5 and $25 \mu \mathrm{M}$ for thiamine and aniline respectively. The substrate specificity showed that the thiaminase from $Z$. variegatus was specific for thiamine and aniline as substrates. The optimum temperature of $Z$. variegatus thiaminase was $50^{\circ} \mathrm{C}$. The native molecular weight of the enzyme as determined by gel filtration was 102,000. The amino acids markedly enhanced the activity of the enzyme. The enzyme was activated by $\mathrm{Mn}^{2+}$, $\mathrm{Ni}^{2+}$ and $\mathrm{Hg}^{2+}$ but inhibited by $\mathrm{Na}^{+}, \mathrm{NH}_{4}{ }^{+}, \mathrm{Co}^{2+}$ and $\mathrm{Zn}^{2+}$. 2-mercaptoethanol and 6-amino hexanoic acid completely inhibited the thiaminase. Z. variegatus should be prepared using extensive and prolong cooking to avoid suffering from thiamine deficiency.

Key Words: Thiaminase; Zonocerus variegatus; Physicochemical Properties; Substrate Inhibition
\end{abstract}

\section{INTRODUCTION}

Thiaminase I (EC. 2.5.1.2) catalyses the decomposition of thiamine by a base exchange reaction involving a nucleophilic displacement on the methylene group of the pyrimidine moiety $[1,2]$. Thiaminase I occurs in a wide range of fish, shellfish, ferns and bacteria [3-5]. Different aromatic amines, heterocyclic bases and sulphydryl compounds have been reported to participate in the hydrolysis of thiamine by thiaminase I. Roberts and Boyd [6] also extended the number of possible co-substrate bases to include a range of commonly used anthelmintics, tranquilizers and anti-histamines. The enzyme has been implicated in a number of diseases in different animals $[3,7]$. Its role in insect metamorphosis has also been established [8].

Hundreds of species of insects have been used as human food [9]. Most people in tropical Africa, Asia and Latin America collect insects for food which has played an important nutritional role [9]. In Africa and the Indians of western North America, the habit is especially well developed among the cultivators of the forest region. It is uncertain whether these insects are eaten because of their nutritional qualities $[10,11]$. Insects and meat play the same role in the human body. Most insects are cheap, tasty and a good natural source of protein and minerals. Many species of insects are lower in fat and higher in protein [9, 12]. The variegated grasshopper, Zonocerus variegatus (Linn.) (Orthoptera: Pyrgomorphidae), which has a large dry season population in Southwestern Nigeria is reported eaten in the Akoko area of Ondo State [13]. The insect has also been reported to be widely eaten in Borno State, North eastern Nigeria [9]. Proximate analysis of $Z$. variegatus revealed that the insect contains high percentage of crude protein $(58.0 \%)$ with an array of essential amino acids and numerous mineral elements in right proportions [9, 14]. Ademolu et al. [15] has also shown the nutritive value of various stages of development of $Z$. variegatus with the adult stage having the highest crude protein content. It is possible this insect species is rich in thiaminase that might be harmful to the population eating it. It is therefore interesting to know the biochemical properties of the thiaminase in order to propose way to treat $Z$. variegatus before consumption. Thus, the present study was designed to quantitatively assess the physicochemical properties of thiaminase. 


\section{MATERIALS AND METHODS}

\section{Materials}

Trizma base, Trizma- $\mathrm{HCl}$, ethylenediamine tetraacetic acid (EDTA), thiamine dichloride and thiamine were purchased from Sigma Chemical Company, St. Louis, Mo., USA. Sodium dodecyl sulphate (SDS), acrylamide and $\mathrm{N}, \mathrm{N}^{1}$-methylene bisacrylamide (MBA), ammonium persulphate, $\mathrm{N}, \mathrm{N}, \mathrm{N}^{1}, \mathrm{~N}^{1}$-tetramethylenediamine (TEMED) are from Eastman, Rochester, NY, USA. All other reagents were of analytical grade and were obtained from either Sigma or BDH. Zonocerus variegatus were collected from an abandoned farmland at the Ladoke Akintola University of Technology, Ogbomoso, Osun State, Nigeria, between October and November, 2010.

\section{Methods}

\section{Thiaminase and Protein Assays.}

Thiaminase activity was determined according to the modified method of Nishimune et al. [8]. The enzyme sample was incubated at $37^{\circ} \mathrm{C}$ in $0.1 \mathrm{M}$ Tris- $\mathrm{HCl}$ buffer, $\mathrm{pH} 8.0$, with $10^{-5} \mathrm{M}$ thiamine and $4 \times 10^{-3} \mathrm{M}$ aniline and incubated for $30 \mathrm{~min}$. This was followed with the addition of $1.0 \mathrm{ml}$ of $200 \mathrm{~g} / \mathrm{l}$ $\mathrm{NaOH}$ and assayed spectrophotometrically. Absorbance was read at $411 \mathrm{~nm}$. One unit of enzyme activity is that amount of enzyme which catalyses the formation of one micromole of heteropyrithiamine in $30 \mathrm{~min}$. The protein concentration was routinely determined by the method of Bradford [16] using bovine serum albumin (BSA) as standard.

\section{Tissue Extraction and Purification}

The gut of $Z$. variegatus was quickly excised and stored in the refrigerator until required. The frozen tissues of $Z$. variegatus were allowed to thaw at room temperature and weighed. A total of $82.8 \mathrm{~g}$ of $Z$. variegatus was used for this preparation. The weighed mass was minced and homogenized in a Warring Blender for $1 \mathrm{~min}$ in three volumes (v/w) of the homogenization buffer containing $0.2 \mathrm{M}$ sodium phosphate buffer, $\mathrm{pH}$ 6.5. The homogenate obtained was stirred, occasionally, for one hour and then subjected to centrifugation at $6,000 \mathrm{rpm}$ at $10^{\circ} \mathrm{C}$ for $30 \mathrm{~min}$. The supernatant was filtered through a double layer of cheese cloth. The cellular debris was resuspended in one volumes of the homogenization buffer and homogenized in the Warring Blender and centrifuged under the same condition. The supernatant obtained was combined with that from the first centrifugation.

DEAE-Cellulose Ion Exchange
Chromatography

A column $(2.5 \times 40 \mathrm{~cm})$ of treated DEAE-Cellulose was packed and equilibrated with $5 \mathrm{mM}$ Tris- $\mathrm{HCl}$ buffer, $\mathrm{pH}$ 7.2. The dialyzed protein from the preceding step was then layered on the column. The column was first washed with $0.1 \mathrm{M}$ Tris- $\mathrm{HCl}$ buffer, $\mathrm{pH} 7.2$ to remove unbound proteins, followed by elution with a $400 \mathrm{ml}$ linear gradient of $0-1.0 \mathrm{M} \mathrm{NaCl}$ in $0.1 \mathrm{M}$ Tris- $\mathrm{HCl}$ buffer, $\mathrm{pH} 7.2$. Fractions of $3 \mathrm{ml}$ were collected from the column that was maintained at a flow rate of $30 \mathrm{ml}$ per hour. Protein was monitored spectrophotometrically using Bradford method. The fractions were also assayed for thiaminase activity. The active fractions were pooled and stored in the refrigerator.

\section{Gel Filtration on Biogel P-100}

Biogel P-100 gel filtration resin was washed with several changes of $0.1 \mathrm{M}$ Tris- $\mathrm{HCl}$ buffer, $\mathrm{pH}$ 7.2. This was then packed unto the column $(2.5 \times 90)$ and equilibrated with $0.1 \mathrm{M}$ Tris- $\mathrm{HCl}$ buffer, $\mathrm{pH}$ 7.2. The enzyme fraction from the preceding step was then applied to the Biogel P-100. Fractions of $5 \mathrm{ml}$ were collected at a flow rate of $10 \mathrm{ml}$ per hour. Protein was monitored spectrophotometrically using Bradford method. The fractions were also assayed for thiaminase activity. The active fractions were pooled.

The native molecular weight was determined on a Biogel P-100 column $(2.5 \times 90 \mathrm{~cm})$. The standard proteins were a-chymotrypsinigen $A\left(M_{r} 24,000 ; 10\right.$ $\mathrm{mg}$ ), ovalbumin ( $\left.\mathrm{M}_{\mathrm{r}} 45,000 ; 10 \mathrm{mg} / \mathrm{ml}\right)$, bovine serum albumin ( $\left.M_{r} 67,000 ; 10 \mathrm{mg} / \mathrm{ml}\right)$, creatinine phosphokinase $\left(\mathrm{Mr}_{\mathrm{r}} 88,000 ; 10 \mathrm{mg} / \mathrm{ml}\right)$ and bovine arginase ( $\mathrm{Mr}_{\mathrm{r}}$ 120,000: $\left.10 \mathrm{mg} / \mathrm{ml}\right)$.

\section{Determination of Kinetic Parameters}

The kinetic parameters $\left(\mathrm{V}_{\max }\right.$ and $\left.\mathrm{K}_{\mathrm{m}}\right)$ of the enzyme were determined according to the modified method of Nishimune et al. (2000). The $\mathrm{K}_{\mathrm{m}}$ of thiamine and aniline were determined by varying the concentrations of thiamine and aniline between $40 \mathrm{mM}$ and $150 \mathrm{mM}$ in $0.1 \mathrm{M}$ Tris- $\mathrm{HCl}$ buffer $\mathrm{pH} 8.0$ respectively. The kinetic parameters were determined from the double reciprocal plot of Lineweaver and Burk [17]. 


\section{Substrate Specificity Studies}

The substrate specificity of grasshopper ( $Z$. variegatus) thiaminase was investigated by testing the activity of the enzyme with two (aniline and thiamine) compounds. The solutions of above compounds $(30 \mathrm{mM})$ were prepared in $0.1 \mathrm{M}$ Tris$\mathrm{HCl}$ buffer, pH 8.0. Enzyme activity was measured by spectrophotometrically as described by [8]. The reaction mixture contained, in final concentration, $0.05 \mathrm{M}$ Tris- $\mathrm{HCl}$ buffer, pH 8.0 containing $30 \mathrm{mM}$ solution of the substrates and $100 \mu$ of the enzyme preparation was added in a final volume of $1.0 \mathrm{ml}$.

\section{Effect of Temperature}

The enzyme was assayed at different temperatures between $30{ }^{\circ} \mathrm{C}$ and $100{ }^{\circ} \mathrm{C}$ to investigate the effect of temperature on the activity of the enzyme and to determine the optimum temperature of the enzyme. The assay mixture was first incubated at the indicated temperature for 30 min before initiating reaction by the addition of an aliquot of the enzyme which had been equilibrated. The residual enzyme was then assayed routinely at 30 mins interval.

\section{Effect of $\mathrm{pH}$ on Thiaminase Activity}

The effect of $\mathrm{pH}$ on thiaminase was studied by assaying the enzyme at different $\mathrm{pH}$ values: $5 \mathrm{mM}$ citrate buffer ( $\mathrm{pH} 5.0-6.5), 5 \mathrm{mM}$ phosphate $(\mathrm{pH}$ 6.5-8.0), $5 \mathrm{mM}$ Tris-HCl buffer (pH 8.0-9.0). A reaction mixture of $1 \mathrm{ml}$ contained $0.4 \mathrm{ml}$ of buffer, $0.2 \mathrm{ml}$ of thiamine, $0.2 \mathrm{ml}$ of aniline, $0.1 \mathrm{ml}$ of enzyme solution.

\section{Effect of Mono and Divalent Metals on Thiaminase Activity \\ The effect of cations on thiaminase activity was studied using the following cations $\mathrm{Zn}^{2+}, \mathrm{Ni}^{2+}$, $\mathrm{NH}_{4}{ }^{+}, \mathrm{Hg}^{2+}, \mathrm{Mn}^{2+}, \mathrm{Co}^{2+}$ and $\mathrm{Na}^{+}$. The enzyme was assayed in a typical enzyme assay. A reaction mixture of $1 \mathrm{ml}$ contained $0.1 \mathrm{mM}$ and $0.2 \mathrm{mM}$ metal concentration.}

\section{Effect of Amino Acids on Thiaminase Activity}

The effect of amino acids on thiaminase activity was studied using the following amino acids; proline, cysteine, valine, and lysine. The enzyme was assayed in a typical enzyme assay. A reaction mixture of $1 \mathrm{ml}$ contained $0.4 \mathrm{ml}$ of buffer, $0.2 \mathrm{ml}$ of thiamine, $0.2 \mathrm{ml}$ of aniline, $0.1 \mathrm{ml}$ of enzyme solution.
Effect of Some Inhibitors on Thiaminase Activity

The effects of 2-mercaptoethanol and 6-amino hexanoic acid on the activity of $Z$. variegatus thiaminase were investigated. $0.5 \mathrm{mM}$ each of the compounds was used in the typical assay reactions.

\section{RESULTS}

\section{Purification of Protein}

The purification of $Z$. variegatus was carried out as described in the materials and methods. The elution profile of the DEAE-Cellulose ion exchange chromatography are shown in Figure 1.

\section{Molecular Weight}

The calibration curve on Biogel P-100 for native molecular weight determination is shown in Figure 2. Gel filtration on Biogel P-100 resulted in a molecular weight estimate of approximately 102,000 daltons.

\section{Determination of Kinetic Parameters}

The substrate specificity and kinetic of thiaminase from gut $Z$. variegatus was investigated by testing its activity towards structurally similar compounds. The compounds include aniline, thiamine and thiamine dihydrochloride. The kinetic parameters $\left(\mathrm{V}_{\max }\right.$ and $\mathrm{K}_{\mathrm{m}}$ ) of thiaminase from the gut of $\mathrm{Z}$. variegatus were determined as described in the text. The kinetic parameter values are shown in Table 1. Figures 3 and 4 shows the Lineweaver Burk plot of thiamine and aniline respectively.

Table 1: Kinetic Properties of Z. variegatus Thiaminase

\begin{tabular}{lcc}
\hline & Thiamine & Aniline \\
\hline $\mathrm{K}_{\mathrm{m}}(\boldsymbol{\mu} \mathrm{M})$ & 5.00 & 25.0 \\
$\mathrm{~V}_{\max }(\mu \mathrm{mole} / \mathrm{ml} / \mathrm{min})$ & 5.00 & 1.11 \\
\hline
\end{tabular}

\footnotetext{
Effect of Temperature and $\mathrm{pH}$ on Thiaminase Activity

The activity of thiaminase was assayed at temperatures between $30{ }^{\circ} \mathrm{C}$ and $100{ }^{\circ} \mathrm{C}$. The optimum temperature of the enzyme was found to be $50^{\circ} \mathrm{C}$ at pH 8.0 (Figure 5). The enzyme activity was markedly enhanced by the amino acids. While the optimum $\mathrm{pH}$ of the enzyme was found to be around pH 8.0 (Figure 6).
} 


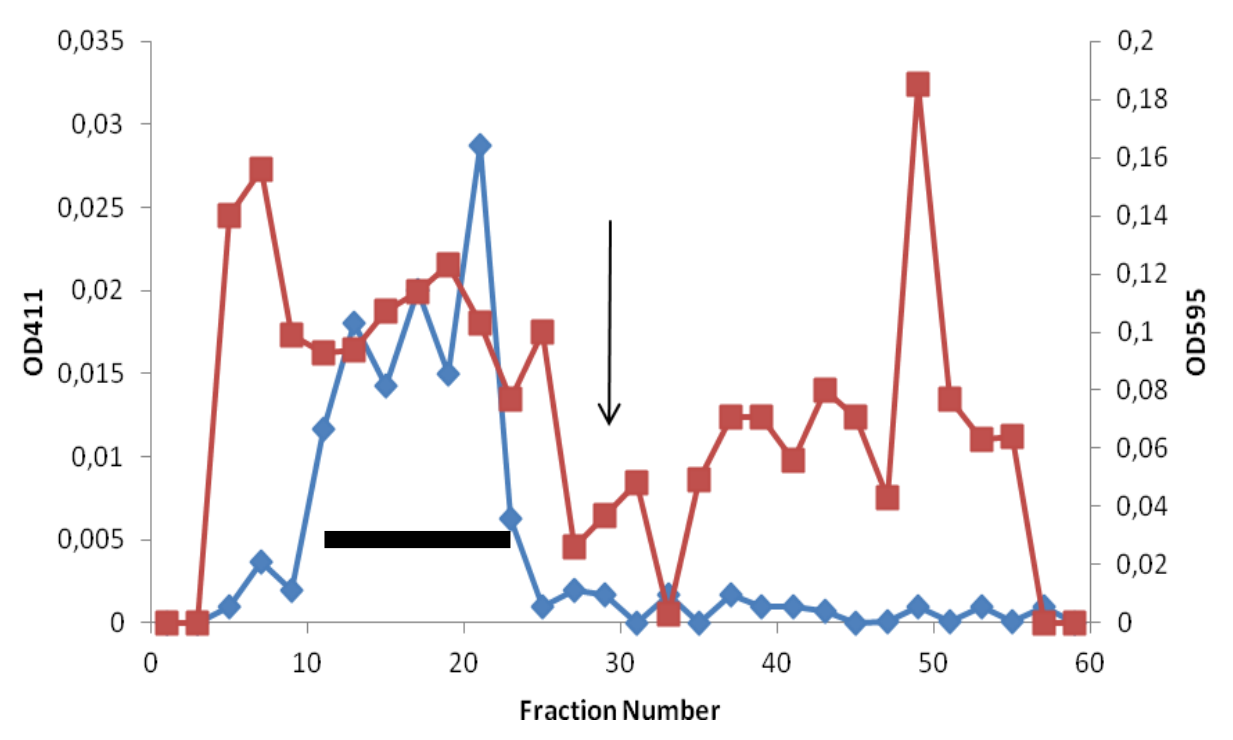

Figure 1: DEAE cellulose lon exchange chromatography of $Z$. variegatus thiaminases. The column was first washed with $100 \mathrm{ml} 0.1 \mathrm{M} \mathrm{Tris-HCl}$ buffer, $\mathrm{pH}$ 7.2. The enzyme solution was layered on the packed column and eluted with a $200 \mathrm{ml}$ linear gradient of $0-1 \mathrm{M} \mathrm{NaCl}$ in $0.1 \mathrm{M} \mathrm{Tris}-\mathrm{HCl}$ buffer, $\mathrm{pH}$ 7.2. Fractions of $1 \mathrm{ml}$ were collected from the column. $-\square-$ - Activity profile; $-\square-$ - Protein profile; $\longrightarrow$ salt concentration gradient; pooled enzyme fraction.

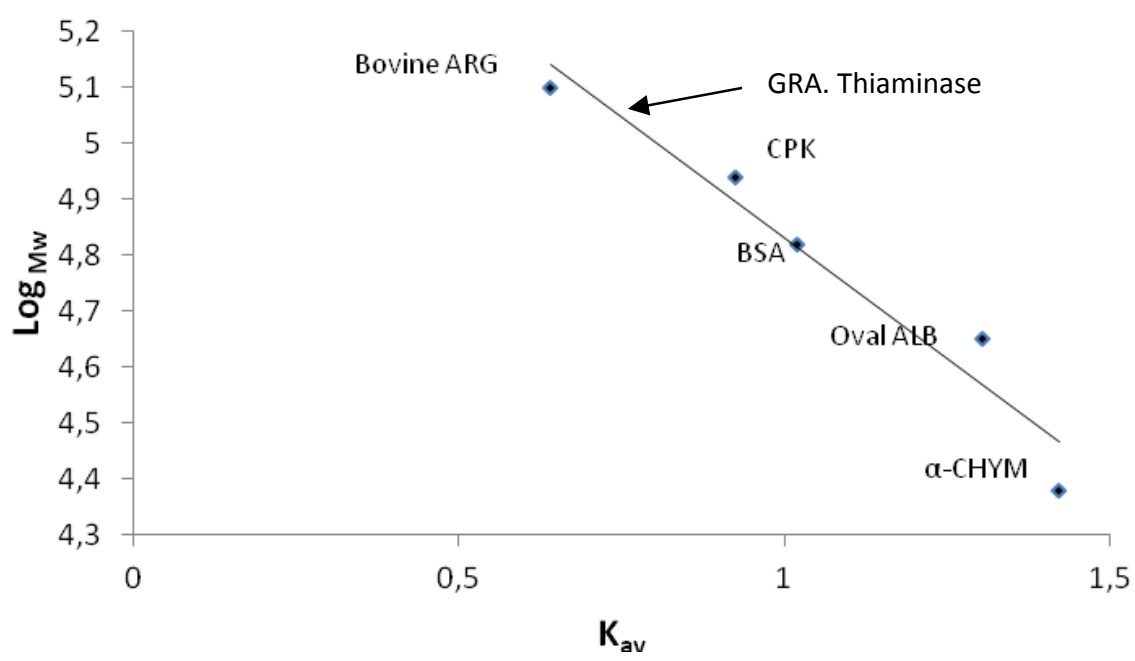

Figure 2: Calibration curve on Biogel P-100 for native molecular weight determination of grasshopper (Z. variegatus Thiaminase). The native molecular weight was determined on a Biogel P-100 column $(2.5 \times 90$ $\mathrm{cm}$ ). The standard proteins as indicated on the curve are a-CHYM (a-chymotrypsinogen A), Oval ALB (ovalbumin), BSA (bovine serum albumin), CPK (creatinine phosphokinase) and Bovine ARG (bovine arginase). Grasshopper thiaminase (GRA. Thiaminase) is indicated by the arrow. 
Effects of Mono and Divalent ions on Thiaminase Activity

The effects of the various cations show that $\mathrm{Mn}^{+2}$, $\mathrm{Ni}^{+2}$ and $\mathrm{Hg}^{+2}$ enhanced the activity of the enzyme while the enzyme was completely inhibited by $\mathrm{Na}^{+}, \mathrm{NH}_{4}^{+}, \mathrm{Zn}^{+2}$ and $\mathrm{Hg}^{+2}$ (Table 2).

\section{Effects of Amino Acid and $\mathrm{pH}$}

The results of the data obtained with the effect of various amino acids on the activity of thiaminase are presented in Table 3.

\section{Effect of Some Inhibitors on Thiaminase Activity}

The effects of 2-mercaptoethanol is shown in Figure 7 . The $Z$. variegatus thiaminase was completely inhibited by 6 -amino hexanoic acid.

Table 2: Effect of Mono and Divalent lons on Z. variegatus Thiaminase Activity

\begin{tabular}{lll}
\hline Metal ion & \multicolumn{2}{l}{$\%$ of Residual Activity } \\
\cline { 2 - 3 } & $\mathbf{1 0 0} \boldsymbol{\mu M}$ & $\mathbf{5 0 0} \boldsymbol{\mu M}$ \\
\hline $\mathrm{Zn}^{2+}$ & $2.10 \%$ & $4.96 \%$ \\
$\mathrm{NH}_{4}{ }^{+}$ & $24.49 \%$ & $10.05 \%$ \\
$\mathrm{Na}^{+}$ & $223 \%$ & $6.55 \%$ \\
$\mathrm{Co}^{2+}$ & $34.24 \%$ & $14.55 \%$ \\
$\mathrm{Ni}^{2+}$ & $100 \%$ & $80.65 \%$ \\
$\mathrm{Hg}^{2+}$ & $87.68 \%$ & $14.57 \%$ \\
$\mathrm{Mn}^{2+}$ & $100 \%$ & $100 \%$ \\
\hline
\end{tabular}

Enzyme assay was carried out using the standard assay mixture containing $0.05 \mathrm{ml}$ of each salt at the final concentrations of $100 \mu \mathrm{M}$ and $500 \mu \mathrm{M}$. The values are mean of duplicate determinations.

Table 3: Effect of Amino Acids on $Z$. variegatus Thiaminase Activity

\begin{tabular}{lc}
\hline $\begin{array}{l}\text { Amino acid } \\
(\mathbf{1 0 0} \mathrm{mM})\end{array}$ & $\begin{array}{l}\% \\
\text { Activity }\end{array}$ \\
\hline Proline & $\begin{array}{c}\text { Residual } \\
\text { Valine }\end{array}$ \\
Lysine & $760 \%$ \\
Cysteine & $60.31 \%$ \\
\hline
\end{tabular}

The reaction mixture contained $0.1 \mathrm{M}$ Tris- $\mathrm{HCl}$ buffer $\mathrm{pH} 8.0,30 \mathrm{mM}$ of the required amino acid and $10 \mu \mathrm{l}$ of the enzyme.

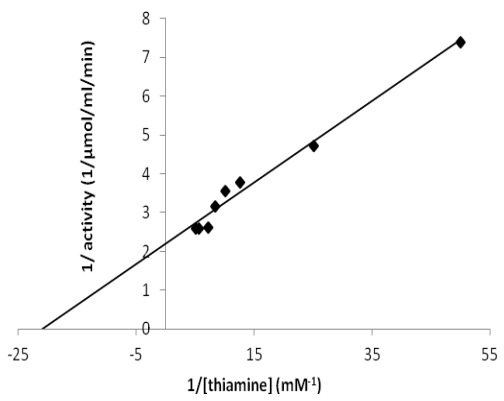

Figure 3: The Lineweaver-Burk plot showing the effect of varying concentrations of thiamine at fixed concentration of aniline on the initial reaction velocity at $\mathrm{pH}$ 8.0. The reaction mixture is as described in the text.

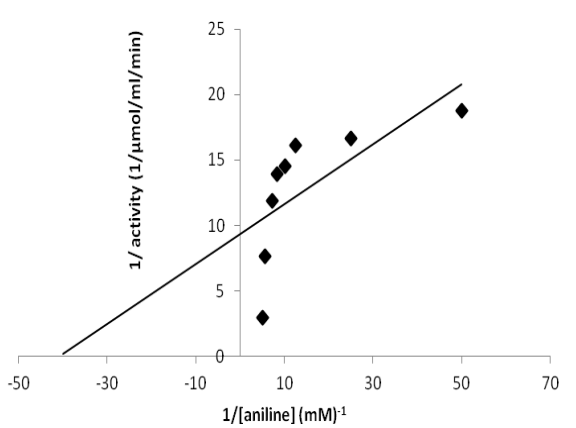

Figure 4: The Lineweaver-Burk plot showing the effect of varying concentrations of aniline at fixed concentration of thiamine on the initial reaction velocity at $\mathrm{pH} 8.0$. The reaction mixture is as described in the text.

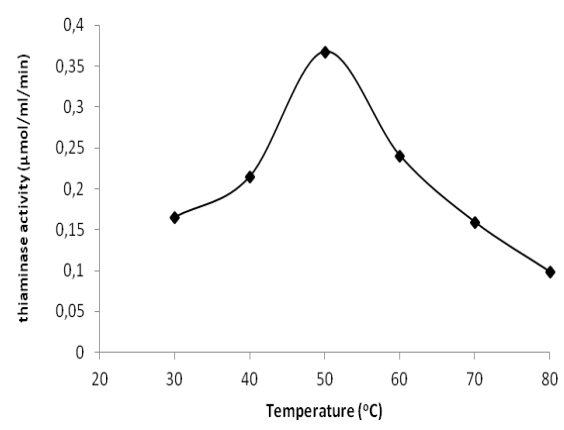

Figure 5: The activity-temperature profile showing the optimum temperature. The activity of $Z$. variegatus thiaminase was assayed at temperatures between $30^{\circ} \mathrm{C}$ and $100^{\circ} \mathrm{C}$. The assay mixture containing $50 \mu \mathrm{l}$ was first incubated at the indicated temperature for $10 \mathrm{~min}$ before initiating the reaction by the addition of an aliquot of the enzyme. 


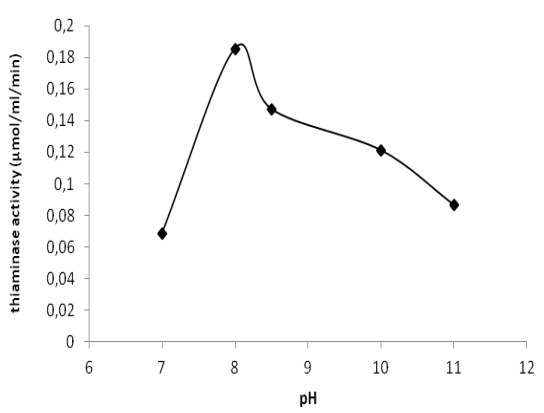

Figure 6: Effect of $\mathrm{pH}$ on Thiaminase Activity of $Z$. variegatus. One $\mathrm{ml}$ of the reaction mixture contained $0.4 \mathrm{ml}$ of the appropriate buffer, $0.2 \mathrm{ml}$ thiamine, $0.2 \mathrm{ml}$ aniline and $0.01 \mathrm{ml}$ enzyme preparation. The following buffers of different $\mathrm{pH}$ values were used for the $\mathrm{pH}$ determination: $5 \mathrm{mM}$ citrate buffer ( $\mathrm{pH}$ 6.0-6.5), $5 \mathrm{mM}$ phosphate (pH 6.5-8.0), $5 \mathrm{mM}$ Tris- $\mathrm{HCl}$ buffer (pH 8.011.0).

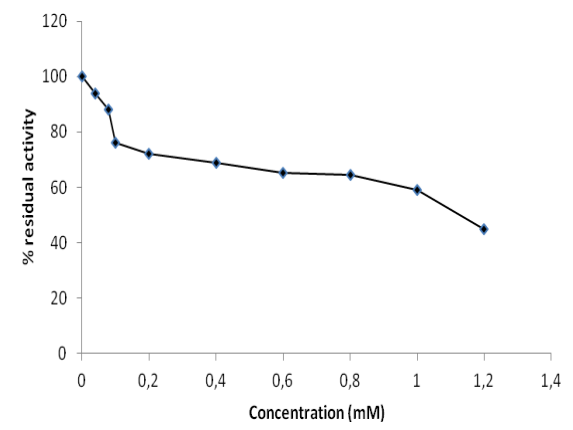

Figure 7: Effect of 2-mercaptoethanol on the activity of thiaminase from gut of $Z$. variegatus

\section{DISCUSSION}

Edible insects constitute an important part of the daily diet of a large proportion of the population in Southwestern Nigeria. These insects provide high quality proteins and supplements (minerals and vitamins) even when dried [9]. The consumption of $Z$. variegatus is becoming popular in Africa [9]. Thiaminase, an antinutritional enzyme was isolated from the gut of Zonocerus variegatus with DEAE-Cellulose ion exchange chromatography and Biogel P-100 gel filtration chromatography. The enzyme had a specific activity of 7.2 micromole/mg of protein. A specific activity of 2.07 micromole/mg of protein was obtained for Nadoo fern thiaminase [1]. [8] obtained a relatively heatresistant thiaminase from the pupae of an African silkworm Anaphe spp.

Molecular weight of the enzyme was 102,000 dalton from gel filtration chromatography on Biogel P-100. This value is close to the molecular weight values of 93,000 - 115,000 dalton for fern nardoo fronds (Marsilea drummondii) and shellfish $[1,18,19,20]$. A very high molecular weight value of 200,000 dalton was reported for Anaphe species [8].

The kinetic parameters obtained are similar to the $\mathrm{K}_{\mathrm{m}}$ reported for the enzyme in other sources. The $\mathrm{K}_{\mathrm{m}}$ presented in Table 1 shows that the enzyme has affinity for thiamine as substrate as compared to the other substrates. [21] reported an apparent Michaelis constant $\left(K_{m}\right)$ of $176 \mathrm{mM}$ and $3.19 \mathrm{mM}$ for thiamine and aniline respectively. Zonocerus variegatus thiaminase is specific for catalyzing thiamine and aniline as the co-substrates. The use of numerous nucleophiles such as aniline, pyridine, and 2-mercaptoethanol by thiaminase enzyme as cosubstrates was reported [22]. [23] used 4-nitrothiophenolate as an alternative substrate for thiaminase I.

Temperature is the most important determinant of metabolic rate in ectothermic animals [24-26] and controls nearly all physiological and biochemical processes [27].

Optimum temperature of $50{ }^{\circ} \mathrm{C}$ was obtained for $Z$. variegatus thiaminase enzyme. The optimum temperature is in the range of optimum temperature reported for the enzyme from other sources. [8] obtained an optimum temperature of $70^{\circ} \mathrm{C}$ with extract of Anaphe pupae thiaminase, a relatively heat-resistant and stable enzyme. Similarly, the optimum pH of 8.0 of $Z$. variegatus thiaminase compares very well with $\mathrm{pH}$ values reported for thiaminases from other organisms [1, 8]. Increases in temperature generally result in increases in physiological processes including metabolic rate. In arthropods, the metabolic rate varies with gender, climate, body weight and parasitism [28-31].

Effect of metal on the enzyme showed the inhibition of the enzyme by $\mathrm{Co}^{2+}, \mathrm{Na}^{+}, \mathrm{NH}_{4}{ }^{+}$and $\mathrm{Zn}^{2+}$ while $\mathrm{Mn}^{2+}, \mathrm{Ni}^{2+}$ and $\mathrm{Hg}^{2+}$ activated the enzyme. [32] had earlier reported the activating effect of $\mathrm{Mn}^{2+}$ and $\mathrm{K}^{+}$on Macrotermes fungus termitomyces and its sensitivity to $\mathrm{Zn}^{2+}, \mathrm{Fe}^{2+}$, and $\mathrm{Cu}^{2+}$. Some amino acids (lysine and valine) were found to slightly inhibit the enzyme while proline and cysteine activated the enzyme. Mercaptoethanol also inhibited the enzyme considerably. [22] had earlier reported the use of 2-mercaptoethanol as a nucleophile substrate in thiamine catalysis. 


\section{CONCLUSION}

The present study has shown the thiaminase from $Z$. variegatus to be thermostable and the physicochemical properties are similar to results obtained from other sources. Though the biological importance of thiaminases in living organism is still unknown, they are involved in impairment of energy producing reactions. In Southwestern Nigeria, edible insects are conceived as food and source of nutrient and the practice of eating $Z$. variegatus is on the increase [9]. This practice should be followed with extensive and prolong cooking of $Z$. variegatus to avoid suffering from thiamine deficiency.

\section{REFERENCES}

1. McCleary B.V. and Chick B.J. 1977. The purification and properties of a thiaminase lenzyme from Nardoo

(Marsilea drummondii). Phytochem. 16:207-213.

2. Toms A.V., Haas A. L., Park J. H., Begley, T. P., and Ealick S.E. 2005. Structural characterization of the regulatory proteins TenA and Tenl from Bacillus subtilis and identification of TenA as a thiaminase II. Biochem. 44: 2319-2329.

3. Tillitt D.E., Zajicek J.L., Brown S. B., Brown L. R., Fitzsimons J. D., Horneyfield D. C., Holey M. E. and Wright G. M. 2005. Thiamine and thiaminase status in forage fish salmonines from Lake Michigan. J. Aqua. Animal Health. 17: $13-25$

4. Shida O., Takagi H., Kadowaki K., Yano H., Abe M., Udaka S. and Komagata K. 1994. Bacillus aneurinolyticus sp. Interna. J. Systemic Bacteriol. 44: 143-150.

5. Stephen C.R. and Allison N.E. 2008. Phylogenetic and ecological characteristics associated with thiaminase activity in Laurentian Great Lake fishes. Trans. Am. Fisheries Soc. 137(1): 147-157.

6. Roberts G.W. and Boyd J.W. 1974. Cerebrocortical necrosis in ruminantsoccurrence of thiaminase in gut of normal and affected animals and its effect on thiamine status. J. Comp. Path. 84:365-374.

7. Ramos J., Marca C., Loste A., García de Jalón J., Fernández A. and Cubel T. 2003. Biochemical changes in apparently normal sheep from flocks affected by polioencephalomalacia. Vet. Res. Commun. 27 (2): 111-124.
8. Nishimune T., Watanabe $Y$., Okazaki $H$. and Akai H. 2000. Thiamin is decomposed due to Anaphe spp. entomophagy in seasonal ataxia patients in Nigeria. J. Nutr. 130: 1625 1628.

9. Solomon M., Ladi O. and Umoru H. 2008. Nutritional evaluation of the giant grasshopper (Zonocerus variegatus) protein and the possible effects of its high dietary fibre on amino acids and mineral bioavailability. Afr. J. Food Agri. Nutr. and Dev. 8(2): 238-248.

10. Banjo A.D., Lawal O. A. and Songonuga A.E. 2006. The nutritional value offourteen species of edible insects in southwestern Nigeria. Afri. J. Biotech. 5(3): 298-301.

11. Sulton M. O. 1988. Insect as food: Aboriginal entomology in the great Basin. Ballena Press Athropo [Paper No 33] Ballena Press, Menlo Park, Califonia. 1-115

12. Dunkel V. and Berenbaum M. 2000. Edible insects. The food Insects News letter. 9 (2): 36.

13. Fasoranti J.O. and Ajiboye D.O. 1993. Some Edible Insects of Kwara State, Nigeria. Amer. Entomol. 39(2):113-116.

14. Olusola L., Solomon M. and Maduka H. 2003. Proximate Chemical Analysis of Zonocerus veriegatus (Giant Grasshopper). Nig J. of Biotech. 14: $42-45$

15. Ademola K. O., Idowu A. B. and Olatunde G. O. 2010. Nutritional value of variegated grasshopper, Zonocerus variegatus (L) (acridoidea: pygomorphidae). Afri. Entomol. 18(2): 360-364.

16. Chiffaud J. and Mestre J. 1990. Le Croquet Puant Zonocerus variegatus (Linne, 1758): Essai de synthese bibliographique. Montpellier: CIRAD-PRIFAS, 140 pp.

17. Bradford M.M. 1976. A rapid and sensitive method for the quantification of microgram quantities of protein, utilizing the principle of protein dye binding. Anal. Biochem. 72, 248254.

18. Lineweaver H. and Burk D. 1934. The determination of enzyme dissociation constants. J. Ame. Chem. Soc. 56: 658-666.

19. Ikehata, H. (1960). The purification of thiaminase II. J. Gen. Microbiol. 6: 30-39

20. Agee C., Wilkins J.H. and Airth R.C. 1973. Cell-bound thiaminase I of Bacillus thiaminolycus. J. Bacteriol. 115: 949-956.

21. Abe M., Ito S., Kimoto M., Hayashi R. and Nishimune T. 1987. Molecular studies 
onthiaminase I. Biochim et Biophysic Acta, 909:213-221.

22. Boyd J.W. 1985. Studies on thiaminase I activity in ruminant faeces and rumen bacteria. J. Agri. Sci. 104: 637-642.

23. Boś M. and Kozik A.J. 2000. Some molecular and enzymatic properties of a homogeneous preparation of thiaminase I purified from carp liver. J. Protein Chem. 19(2):75-84.

24. Hanes J.W., Kraft C. E. and Begle, T.P. 2007. An assay for thiaminase $I$ in complex biological samples. Anal. Biochem. 368: 3338.

25. Cosins P. and Bowler K. 1987. Temperature biology of animals. Chapman and Hall, London. pp. 61-91.

26. Hawkins A.J. 1995. Effects of temperature change on ectotherm metabolism and evolution: Metabolic and physiological interrelations underlying the superiority of multi-locus heterozygotes in heterogeneous environments. J. Thermal Biol. 20: 23-33.

27. Angilletta M.J., Niewiarowski P.H. and Navas, C.A. 2002. The evolution of thermal physiology in ectotherms. J. Thermal Biol. 27: 214-231.
28. Huey R.B. and Berrigan D. 2001. Temperature, demography, and ectotherm fitness. Nature. 158: 204-210.

29. Nielsen M.G., Elmes G.W. and Kipyatkov V.E. 1999. Respiratory Q10 varies betweenpopulations of two species of Myrmica ants according to the latitude of their sites. J. Insect Physiol. 45: 559-564.

30. Rogowitz G.L. and Chappell M.A. 2000. Energy metabolism of eucalyptus-boring beetles at rest and during locomotion: gender makes a difference. J. Experim. Biol. 203: 1131-1139.

31. Gillooly J.F., Brown J.H. and West G.B. 2001. Effects of size and temperature on metabolic rate. Science 21: 2248-2251.

32. Kolluru G.R., Zuk M. and Chappell M.A. 2002. Reduced reproductive effort in male fieldcrickets infested with parasitoid fly larvae. Behav. and Ecol. 13: 607-614.

33. Faulet B.M., Niamké S., Gonnety J.T. and Kou L.P. 2006. Purification and biochemical properties of a new thermostable xylanase from symbiotic fungus, Termitomyces sp. Afr. J. Biotech. 5(3): 273-282. 